\title{
Gynandromorphy in Eulaema atleticana Nemésio (Apidae, Euglossini)
}

\author{
Maxwell Souza Silveira ${ }^{\circledR}{ }^{\bowtie}$, Maria Helena Pereira Peixoto ${ }^{2}$, Celso Feitosa Martins ${ }^{2} \&$ \\ Fernando César Vieira Zanella ${ }^{3}$
}

1. Univesidade Federal da Bahia, e-mail: silveira.m.s@bol.com.br (Autor para correspondência ${ }^{\varpi}$ ). 2. Universidade Federal da Paraíba, e-mail: peixotop@leuphana.de, cmartins@dse.ufpb.br. 3. Universidade Federal de Campina Grande, e-mail: fcvzanella@gmail.com.

EntomoBrasilis 5 (3): 238-241 (2012)

Abstract. A gynandromorph specimen of Eulaema atleticana Nemésio, the first registered in Eulaema, is described. The E. atleticana gynandromorph was captured using an eucalyptol scent trap, in the Mata do Buraquinho Reserve, an Atlantic Forest fragment. The study site has 550 ha and is located in the urban area of the Municipality of João Pessoa, State of Paraíba, Northeast Brazil. The specimen presents antero-posterior and bilateral asymmetry. The head presents only male morphological characteristics. The mesosoma is composed by male and female structures, with male fore and middle legs. The right hind tibia shows a mosaic of male and female characters, with rudiments of the tibial organ and a corbicula. The metasoma presents only female characters.

Keywords: Bees; Euglossina; Gynandromorph; Sexual dimorphism.

\section{Gynandromorfia em Eulaema atleticana Nemésio (Apidae, Euglossini)}

Resumo. É descrito um espécime ginandromorfo de Eulaema atleticana Nemésio. O primeiro registrado em Eulaema. O espécime foi coletado em armadilha de cheiro, na reserva da Mata do Buraquinho, um fragmento de Mata Atlântica, localizado no perímetro urbano da cidade de João Pessoa, Paraíba, Nordeste, Brasil. O espécime apresenta assimetria bilateral e anteroposterior. A cabeça possui apenas caracteres de macho. O mesossoma é composto por caracteres de macho e fêmea, com as pernas anteriores e medianas apresentando caracteres de macho. Nas pernas posteriores, a tíbia direita apresenta um mosaico de caracteres masculinos e femininos com rudimentos do órgão tibial e da corbícula. Todas as características do metassoma são de fêmea.

Palavras-Chave: Abelhas; Euglossina, Dimorfismo sexual; Ginandromorfo.

$\mathbf{O}$ ne of the first occurrences of gynandromorphy in bees registered in the literature was a case of bilateral asymmetry in Bombuslapidarius Linaeus. In this species, the male characters are present on the left side and the female characters on the right side of a specimen (SchiEL 1858). Recent studies showed this anomaly in Alloscirtetica brethesi Joergensen (Urban 1999) and Megachile (Austromegachile) montesuma Cresson (Gonzalez 2004). WCislo et al. (2004) reported a case of gynandromorphy in Megalopta genalis Mead-Waldo. These authors also made a literature review that presents a list with 72 cases of gynandromorphy in 6 families and in 64 species of bees. More recently, Oliveira \& ANDRADE (2006a, 2006b) described two occurrences of bilateral asymmetry in Melipona mondury Smith, and Lucia et al (2009) reported a mix between anterior-posterior and bilateral asymmetry.

This paper presents the first record of gynandromorphy in Eulaema and describes an anterior-posterior and bilateral asymmetry in Eulaema atleticana Nemésio.

The $E$. atleticana gynandromorph was captured using eucalyptol scent trap, in the Mata do Buraquinho Reserve, an Atlantic Forest fragment. The study site has 550 ha located in the urban area of João Pessoa city, State of Paraíba, Northeast Brazil (07 $07^{\circ}$ 'S$\left.34^{\circ} 51^{\prime} \mathrm{W}\right)$. The specimen was analyzed and photographed with a stereoscopic microscope Leica-Wild $®$ M205C using LAS software and photographed also by utilizing a Pentax ${ }^{\circledR}$ istD camera, coupled to a $100 \mathrm{~mm}$ objective lens. The specimen here reported is currently deposited at the Entomological Collection (DSEC) of the 'Universidade Federal da Paraíba', with the following label data: Eulaema atleticana, "22611" and "Brasil, PB, João Pessoa, Mata do Buraquinho, Eucaliptol 21/II/2006 M.H.P.Peixoto \& M.S. Silveira cols.”. The female showed in the figure is deposited at the same collection with the following label data: Eulaema atleticana, "22612" and "Brasil, PB, UFPB Campus I, 11/IV/2003 M.H.P.Peixoto col.”.

The phenotypic variation between male and female characters occurs on the anterior-posterior and bilateral direction. The male characters are present on the anterior portion, including head and mesosoma. Female characters are on the left tibia and metasoma (Figure 1). The head appendices do not present anomalies. The fore and middle legs are as in normal males, with tarsal brushes on the anterior legs and velvet area and coxins on the middle tibias. The posterior left leg is as in normal males, with intumesced tibia, tibial fissure and internal spongiform tissues with normal aspect (Figure 2). The right tibia shows a mosaic of male and female characters. The tibial fissure is located on the external lateral face, instead of being on the superior edge; it occurs in the form of a hole with hair tiers on the edge. The internal spongiform tissues are almost absent and the cavity is nearly hollow. The largest area of the right tibia has the aspect of a rudimentary corbicula, with some plumose hairs (Figure 3) similar to a normal corbicula present in females (Figure 4). 
The metasoma do not present anomalies. The genital structure presents a developed and functional sting as in normal females (Figure 5).

The irregular distribution and the great amount of combinations between male and female characters over the specimen body show a mixed pattern between anterior-posterior and bilateral asymmetry. This categorization is according to DALLA TORRE \& FRIESE (1889) that classified gynandromorphy in four types of asymmetry: anterior-posterior, bilateral, transverse and mixed. The last type of asymmetry is the most described for bees (WCISLO et al 2004). This is the first study that describes behavioral aspects of males and females in a gynandromorph specimen, in addition to the morphological characters of Euglossini. The gynandromorph described was observed hovering around the scent trap and using the tarsal brushes present on anterior legs to collect the essence of eucalyptol deposited on a cotton swab. The behavior of collecting chemical compounds is unique to Euglossini males, which present morphological and behavioral adaptations for compounds collection. Therefore, only males of these bees are attracted by the sampling technique utilized in this study. To be removed from net, the reported specimen displayed a female defensive behavior, stinging the researcher. Thus, the $E$. atleticana gynandromorph showed a female and male behavior.

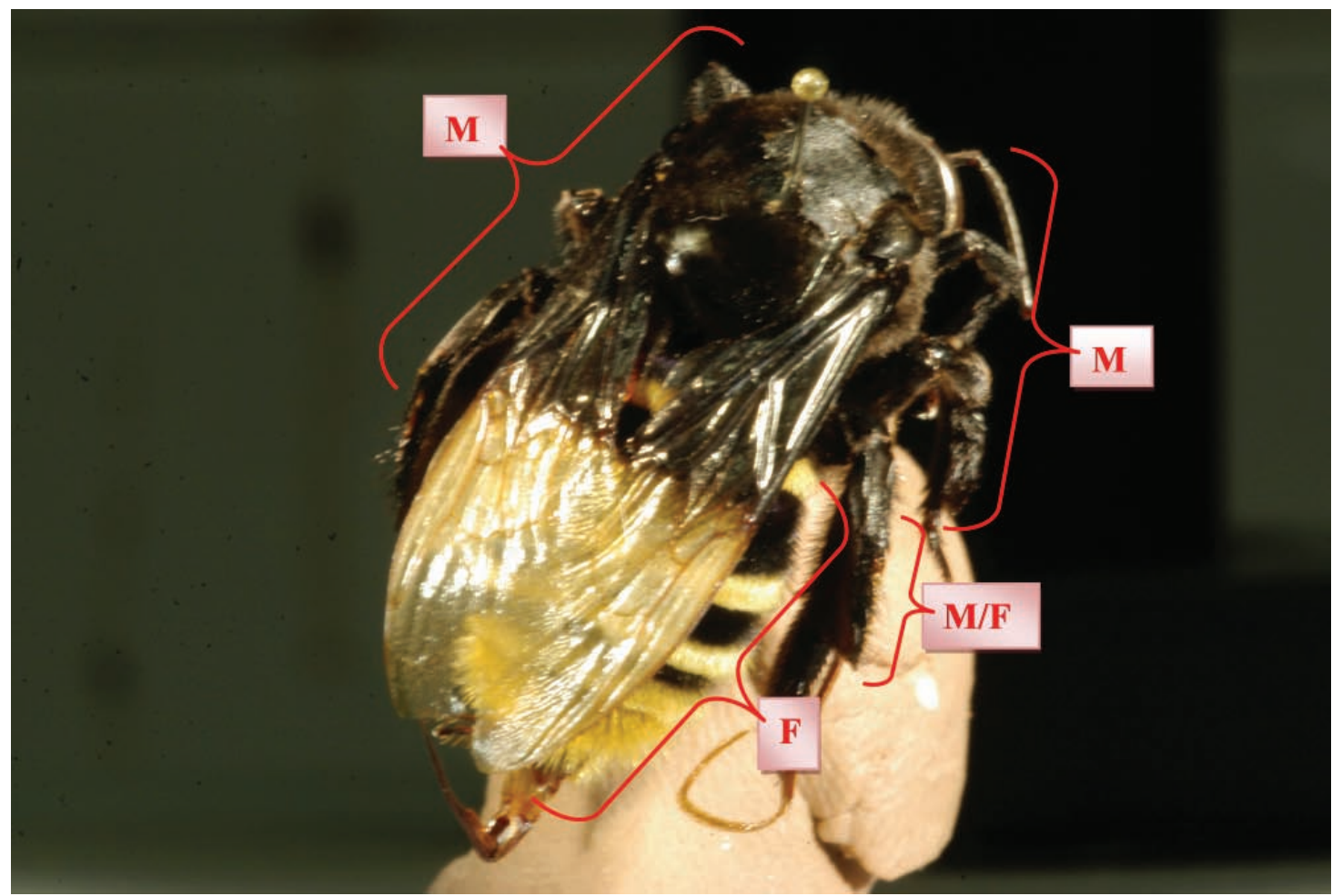

Figure 1. Distribution of male and female characters over the $E$. atleticana gynandromorph specimen body $(\mathrm{M}=$ male, $\mathrm{F}=\mathrm{female}, \mathrm{M} / \mathrm{F}=\mathrm{mosaic}$ of $\mathrm{male}$ and female characters).

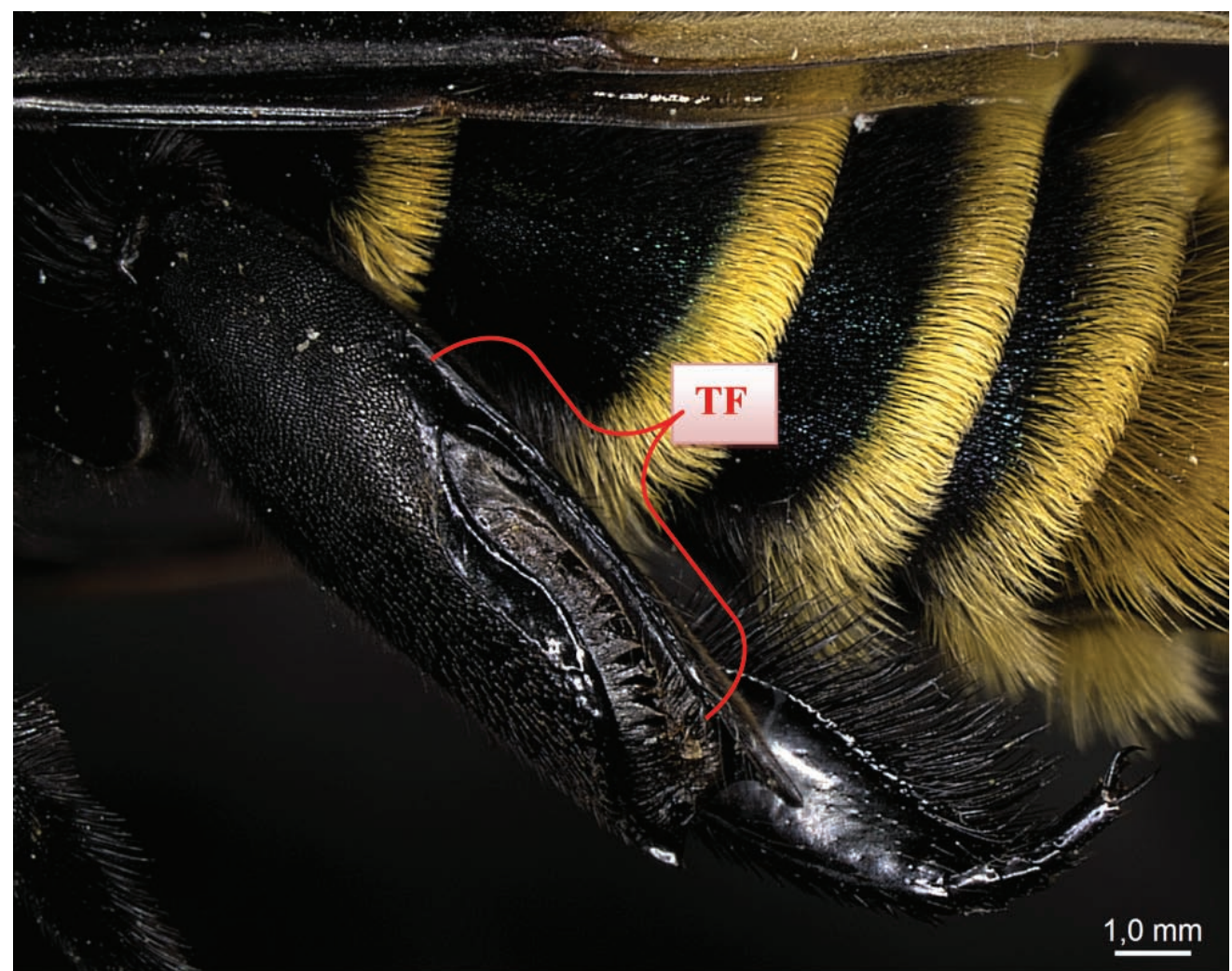

Figure 2. Left hind tibia with tibial organ, characteristic of Euglossina males (TF = tibial fissure). 


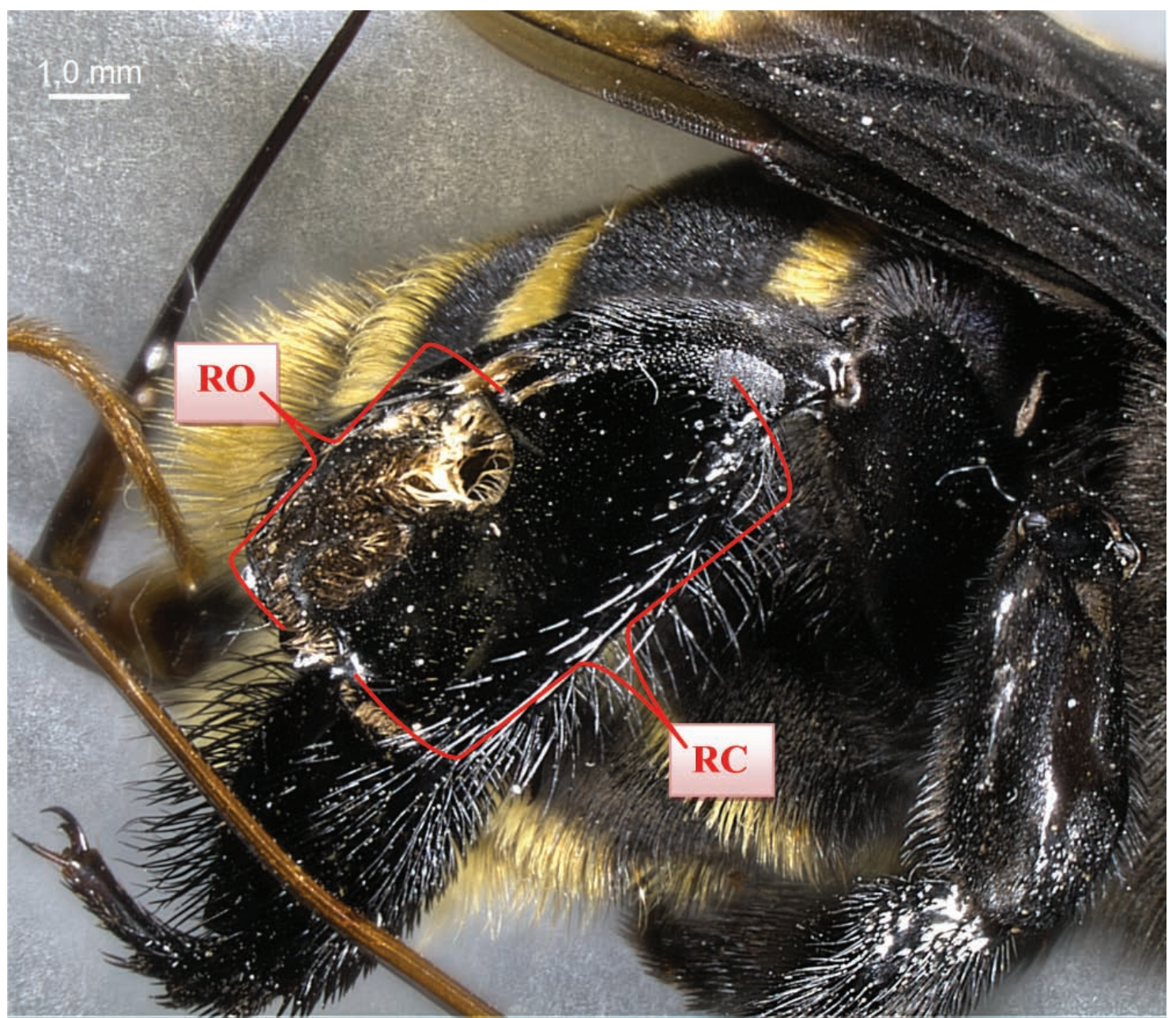

Figure 3. Detail from the right hind tibia $(\mathrm{RO}=$ rudimentary tibial organ, $\mathrm{RC}=$ rudimentary corbicula).

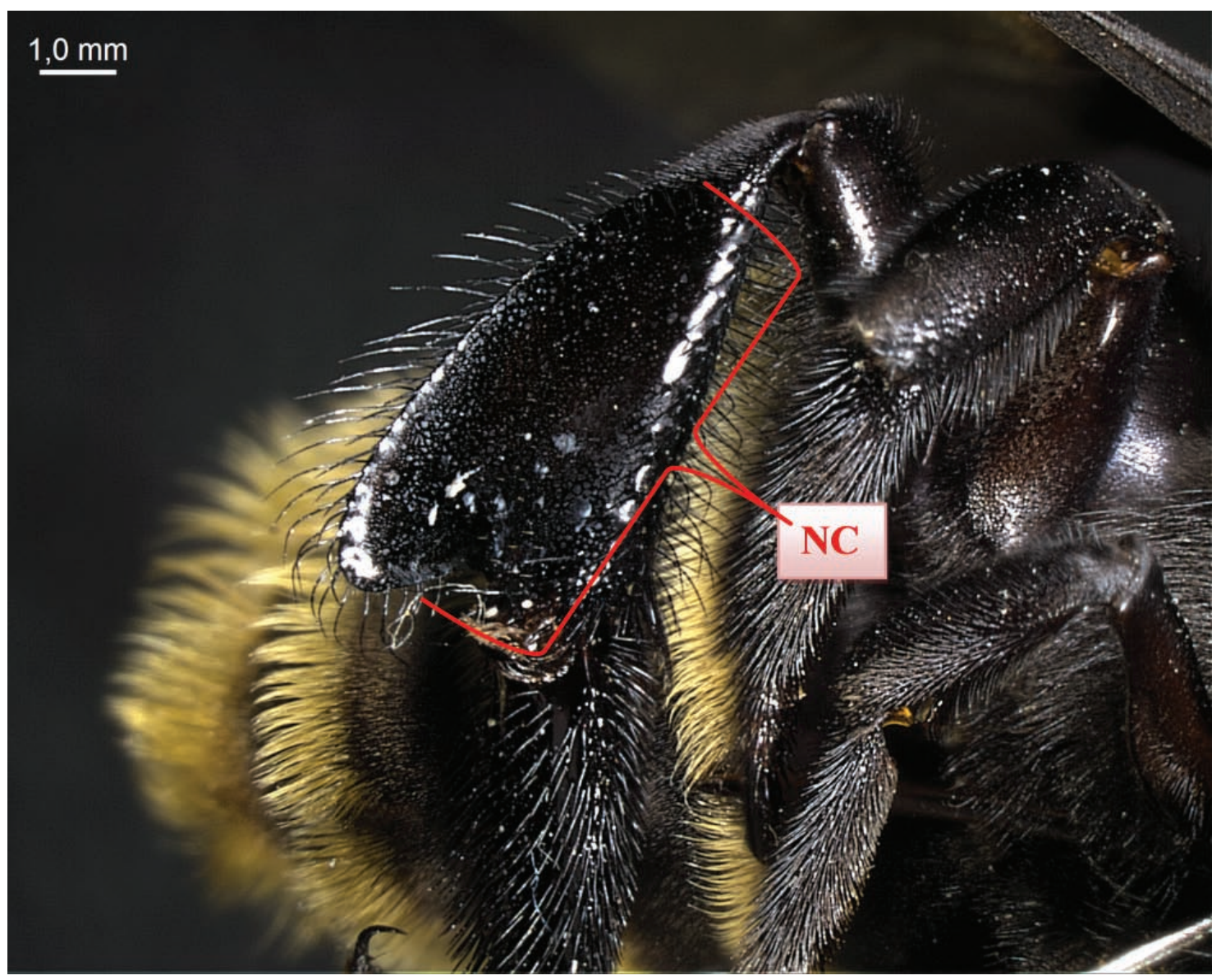

Figure 4. E. atleticana female with normal corbicula $(\mathrm{NC}=$ normal corbicula). 


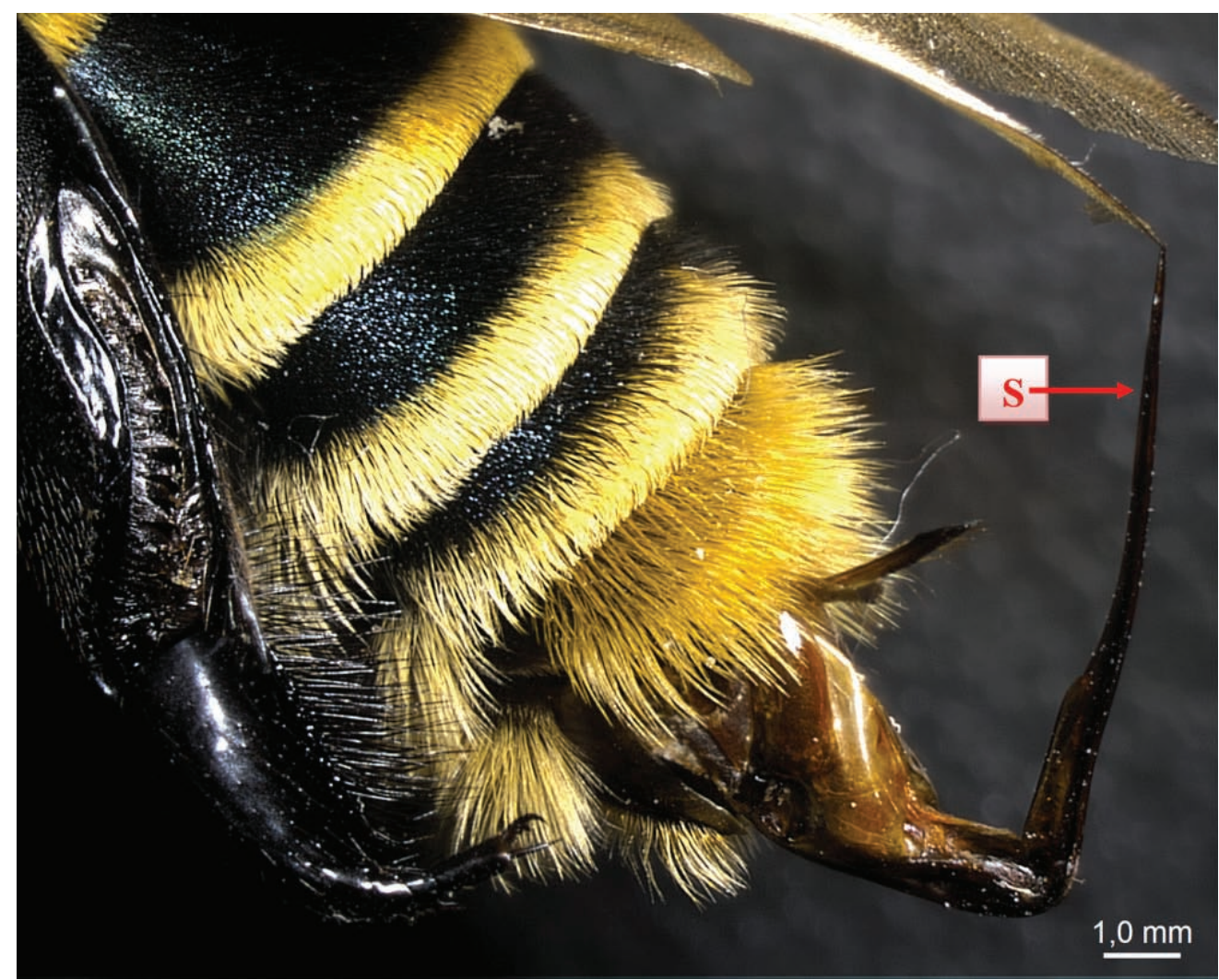

Figure 5. Metassoma from Ginandromorph with funcional sting ( $\mathrm{S}=$ sting).

\section{ACKNOWLEDGMENTS}

We are grateful to Coordenação de Aperfeiçoamento de Pessoal de Nível Superior (Capes) for granting scholarships to the first two authors and to the staff of Instituto Brasileiro do Meio Ambiente from Mata do Buraquinho (IBAMA) for their support during the surveys and M.Sc. Carolina Liberal for the help with the photographs.

\section{REFERENCES}

Dalla Torre, K.W., Friese, H., 1899. Die hermaphroditen und gynandromorphen Hymenopteren. Bericht des Naturwissenschaftlich-Medizinischen Vereins Innsbruck, 24:1-96.

Gonzalez, V.H., 2004. A gynandromorph of Megachile (Austromegachile) montezuma Cresson (Hymenoptera, Apoidea, Megachilidae). Entomotropica, 19: 155-156.

Lucia, M., A.H. Abrahamovich \& L.J. Alvarez, 2009. A Gynandromorph of Xylocopa nigrocincta Smith (Hymenoptera: Apidae). Neotropical Entomology, 38: 155157.
Oliveira, F.F. \& M.A.P. Andrade, 2006a. Ginadromorfia em Melipona mondury Smith (Hymenoptera, Apidae, Meliponinae). Sitientibus, 6: 272-276.

Oliveira. F.F. \& M.A.P. Andrade, 2006b. Outro caso de ginandromorfia em Melipona mondury Smith (Hymenoptera, Apidae, Meliponinae). Magistra, 18: 284-287.

Sichel, J., 1858. Note sur un insecte himenóptére hermaphrodite (Bombus lapidarius). Annales de la Société Entomologique de France, 17: 247-249.

Urban, D., 1999. Ginandromorfia em Alloscirtetica brethesi (Hymenoptera, Anthophoridae). Revista Brasileira de Zoologia, 16: 171-173.

Wcislo, W.T., V.H. Gonzalez \& L. Arneson, 2004. A review of deviant phenotypes in bees in relation to brood parasitism, and a gynandromorph of Megalopta genalis (Hymenoptera, Halictidae). Journal of Natural History, 38: 1443-1457.

\section{Recebido em: 27/07/2011}

Aceito em: 22/09/2012

Como citar este artigo:

Silveira, M.S., M.H.P. Peixoto, C.F. Martins \& F.C.V. Zanella, 2012. Gynandromorphy in Eulaema atleticana Nemésio (Apidae, Euglossini). EntomoBrasilis, 5(3): 238-241.

Acessível em: http://www.periodico.ebras.bio.br/ojs/index.php/ebras/article/view/172
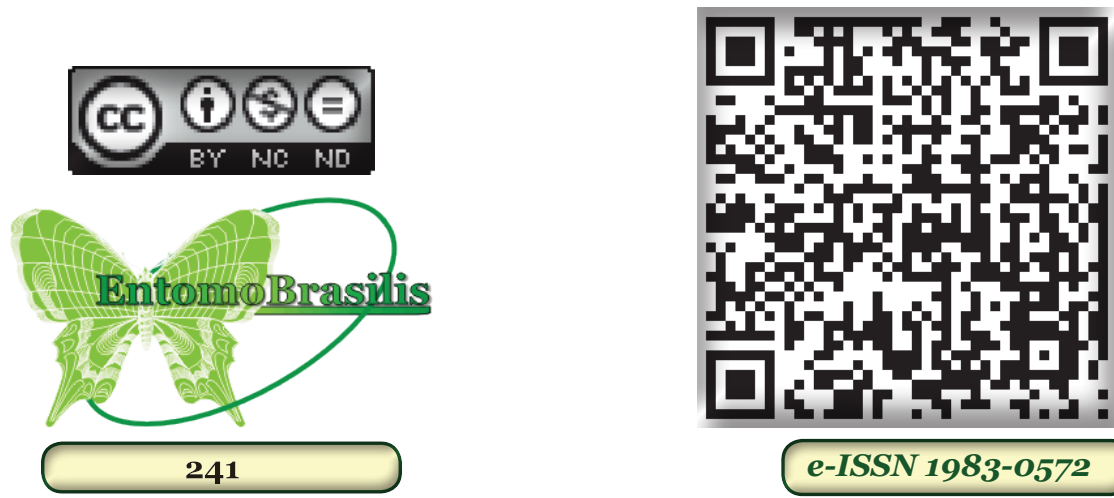